\title{
Missionêre diakonaat: 'n Uitdaging vir die kerk
}

\author{
P J W Schutte ${ }^{1}$ \\ Departement Nuwe-Testamentiese Wetenskap \\ Universiteit van Pretoria
}

\begin{abstract}
Missionary diakonia: A challenge to the church

This article seeks to show the importance of diakonia as a ministry of the church, not only as a service in the church, but also as a service to the community in which Christians and the church live. To establish diakonia in that sense, also as a missionary activity, some paradigm shifts would be necessary. This article prepares the ground for the initial steps in that direction.
\end{abstract}

\section{INLEIDING}

Die kerk bestaan nie los van die wêreld nie. Die kerk self is 'n stuk wêreld waarop God beslag gelê het en waar sy oorname met vreugde en dankbaarheid aanvaar is. Voor die sondeval was daar geen kerk gewees nie en aan die einde van alles sal daar ook geen kerk wees nie. Maar totdat die volheid aanbreek en die skepping sy eindbestemming bereik, kan die wêreld nie sonder die kerk nie.

Die kerk het voor God 'n verantwoordelikheid ten opsigte van die wêreld. In die wêreld moet die kerk haar boodskap verkondig en haar heil in Christus vier, anders verloor sy die wêreld. En 'n kerk wat haar greep en oog vir die wêreld verloor het, het eintlik alles verloor.

Hierdie oog wat die kerk vir die wêreld moet hê, is volgens Nicea een van die wesenseienskappe van die kerk. Afgesien van die eenheid, heiligheid en algemeenheid van die kerk, is die kerk volgens Nicea ook nog apostolies. Dit

\footnotetext{
1 Dr P J W Schutte, predikant in die Nederduitsch Hervormde Gemeente Klerksdorp, is PhDstudent in die Departement Nuwe-Testamentiese Wetenskap, Universiteit van Pretoria.
} 
beteken dat die kerk gestuurde na die wêreld is en dat die kerk altyd 'n gerigtheid op die wêreld moet hê (Moltmann 1977:339).

Omdat die apostolisiteit van die kerk deel van haar wese is, is dit ook deel van al haar werk. Hierdie apostolaatsbewussyn wat deel van die kerk se identiteit is, maak van die kerk 'n missionêre kerk. 'n Kerk wat 'n boodskap vir die wêreld het. Maar dan nie net 'n boodskap in woorde nie, ook 'n boodskap in dade.

Hierdie boodskap vind sy inhoud in die barmhartigheid wat God aan ons bewys het deur die persoon en werk van sy Seun (Rossouw 1991:487). Jesus Christus het deur sy lewe en bediening die barmhartigheid van die Vader omgesit in brood, genesing, redding uit gevaar, vergifnis en versoening met God. Hy konkretiseer in Persoon en werk die hart van die Vader (Nel 1994:232).

Mens sou dus die argument kon saamvat deur soos Koekemoer (1993:12) te sê: "Die diens van die heilige, regverdige God wat sy wêreld liefhet, kry gestalte in die diens van Jesus Christus wat in wese versoeningswerk is. Dat God die mens dien, impliseer dat Hy die mens met Homself versoen. Dit is hierdie diakonia, so sentraal in die Christologie, wat die deur behoort te vorm vir ons ingang tot besinning oor ons eie Christelike barmhartigheidsdiens. God se dienswerk moet in ons dienswerk verklank word."

Die diens van die barmhartigheid is nog altyd in die Kerk as 'n Godgegewe opdrag en roeping gesien waartoe elke lidmaat ' $n$ verantwoordelikheid het (Botha 1993:47). In die plaaslike gemeente het die diakens in die besonder die taak om hierdie dienswerk te organiseer, te lei en te behartig. Dit word nie die alleen verantwoordelikheid van die diakens nie. Dit bly elke lidmaat se roeping en opdrag.

Die feit dat God die wêreld liefhet en dat die kerk 'n boodskap vir die wêreld het, maak dat die plaaslike gemeente nie anders kan as om missionêr by haar gemeenskap betrokke te raak nie. Ook wat haar barmhartigheidsdienswerk betref. Die gemeente moet volgens Nel (1994:232) met haar dienswerk in die wêreld uitdrukking gee aan die barmhartige hulpvaardigheid van God.

Barmhartigheid, of koinoniale gemeentediakonaat, is dus die handeling van die Drie-enige God in hierdie wêreld waardeur Hy homself aan mense in nood wil openbaar (Oosthuizen \& Strauss 1995:52). Die Sharing and Service Commission van die WRK het na die Canberra beraad van 1992 die volgende definisie vir diakonia geformuleer: "Diakonia is the 'active expression of Christian 
witness in response to the needs and challenges of the community in which Christians and the churches live.' Or in Orthodox terms 'diakonia at heart, is the sharing of suffering, the carrying of one another's burdens, thus fulfilling the law of Christ' ... Diakonia as the expression of Christian love and sharing is inclusive 'it includes social struggles and development activities as well as enviromental concerns, as witness in action."' (Blyth en Robins 1998:23)

Die vraag wat die kerk voortdurend vir haarself moet vra ten opsigte van haar betrokkenheid by die wêreld, is: "Spreekt de kerk de mondige en moderne mens nog wel aan? Sluit de kerk in haar activiteiten wel voldoende aan bij de leefwereld van de geseculariseerde mens?" (Peters 2000:25).

Die doel van hierdie artikel is om, met alles wat hierbo gesê is, na die huidige praxis ten opsigte van barmhartigheidsdiens te kyk en om dan te vra hoeveel daarvan tereg kom, nie net in die gemeente nie, maar veral ook buite die grense van die gemeente. Die artikel vra dan juis ook na die paradigmaskuif wat moet plaasvind sodat die nood nie net binne nie, maar ook buite die gemeente raakgesien en aangespreek word. Dit wil die gemeente dus aanmoedig om ook missionêr met die diakonaat besig te wees.

\section{DIE HUIDIGE PRAXIS}

"Simply understanding the past will not tell us how to plan for the future, but it is a necessary step. Different ages provide different opportunities and experience different limitations" (McKee 1989:4). Dit is waarom dit nodig is om na die verlede en die hede te kyk voordat 'n mens vir die toekoms kan beplan.

Die rol wat die meeste diakens tans in die kerk speel, kan soos volg opgesom word: Die diaken is in die gemeente verantwoordelik vir: (a) die insameling van offers en gawes van die gemeente; (b) die bediening van die offergawes aan die armes; (c) die beheer en die beskikking oor die diakonale gelde en goedere. Benewens hierdie pligte ten behoewe van die armes, word van hulle ook verwag om die dienaar van die Woord aan die tafel van die Here by te staan, en om as ampsdraer in die gemeente teenwoordig te wees by die bediening van Woord en Sakramente (Engelbrecht 1957:17).

Dit is hoe die amp van die diaken tradisioneel verstaan word en gestalte kry in die praxis van die gemeente. 
Ben Engelbrecht (1957:17) skryf reeds in 1957 dat daar 'n nouer band tussen die dienswerk van die diaken en die bediening van die Woord behoort te bestaan. Die praktiese uitvloeisel daarvan is dat die diaken en die bedienaar van die Woord heel dikwels oorleg sal moet pleeg en saam 'n bedieningstrategie ten opsigte van 'n bepaalde situasie sal moet uitwerk.

Hierdie verbondenheid tussen woord en daad/hulpverlening, word vandag heel dikwels in die kerk vergeet, "met die gevolg dat die diaken en sy amp verklein word tot die van 'n ywerige kollektant om kerkskuld af te betaal. So moet dit volgens die Woord van God nie wees nie. Die diaken het volgens die Woord 'n veel hoër amp. Hy is geen finansiële amptenaar nie, maar beklee 'n kerklike amp. Die insameling van algemene gemeentelike kollektes, wat so dikwels deur ons as die hooftaak van die diaken gesien word, is hoogstens hulpdiens wat hy vir die kerkraad uit vriendelikheid doen, maar is geen ampswerk nie. Die diaken se eintlike ampswerk is die diens van die barmhartigheid" (Engelbrecht 1957:17). Peters (2000:26) onderstreep ook hierdie punt as hy sê: 'Gemeenten zijn soms te veel gericht op de strategie van het 'overleven' en zijn daardoor zeer naar binnen gekeerd. Er wordt dan nauwelijks nagedacht over, laat staan vorm gegeven aan de missionaire roeping naar buiten en het opkomen voor de zwakken in de sameleving en wereldwijd."

Naas die feit dat die diaken 'n blote kollektant geword het, is die volgende dillema dat baie van die barmhartigheidswerk in die kerk geïnstitusionaliseerd geraak het. Daar is tehuise vir bejaardes, kinderhuise en welsynsorganisasies. Kyk 'n mens na die samestelling van die diakonale rade en na die direksies van die tehuise, is daar dikwels meer predikante en ander persone by betrokke, as diakens. Die diaken word "heel indirek betrek ... omdat hulle die goeie middele moet versamel om die inrigtings in stand te hou" (Booysen 1993:54).

Op gemeentevlak beteken barmhartigheidswerk weinig kere iets meer as kos en klere wat by 'n gesin in nood afgelaai word. Dikwels word die verdienstelikheid en meriete van 'n geval ook nog eers deur 'n kommissie ondersoek voordat hulp verleen word. Daar kom dus maar min tereg van die barmhartigheid wat Christus as Hoof van sy kerk wil laat uitstraal deur die lede van sy liggaam aan mekaar tot opbou, en aan die wêreld tot uitbou en tot diens (Rossouw 1991:487).

Die diaken se rol is dus tans primêr die van middeleversamelaar om hierdie dienste in stand te hou. Min, indien enige, diakonaatsagendas het 'n punt 
soos "missionêre aktiwiteite" wat by vergaderings lewendig deur die diakens bespreek word. McKee (1989:108) sê: "Deacons should not be ignorant about pastoral needs in the congregation or community, but their fundamental task is leading the church in justice and caring ministries."

Min, indien enige, lidmate word toegerus of, anders as net finansieel, betrek by die gemeentelike diakonaat. En min, indien enige, lidmate of ampsdraers sien diakonaat op missionêre vlak as deel van die kerk, en meer spesifiek, die plaaslike gemeente, se bediening.

\section{DIAKONALE PARADIGMASKUIWE}

Die kerk, in haar onderskeie gemeentes, is al vir die afgelope twee millenniums besig met haar bediening na binne en na buite. "De gemeente is een belangrijke schakel in het vertalen van wie God wil zijn voor mensen. Wanneer de gemeente iets weerspiegelt van zijn liefde, zal het voor mensen beter te ervaren zijn" (Peters 2000:28). In hierdie gehoorsame uitleef van die kerk se roeping en opdrag ervaar die kerk "a special pressure emerging from its belief that the Lord had given it a double-edged commandment - it was to engage with the world, to love the world, to serve the world, to convert the world. And yet it was also to maintain itself as in some sense 'distinct from' the world. It was to be a 'peculiar people', as Peter put it, but the peculiarity had much to do with caring and serving that world for God" (Mead 1993:9).

Hierdie dialektiese spanning tesame met die reformatoriese aard van die kerk maak dit 'n sine qua non dat die kerk voortdurend besig moet wees met selfondersoek, evaluering en aanpassings om haar roeping opnuut te interpreter en om gehoorsaam daaraan te bly.

As die diakonaat weer 'n slag bekyk word, blyk dit dat daar, gemeet aan die huidige praxis, bepaalde paradigmaskuiwe gemaak sal moet word. Die belangrikste aspekte waaraan aandag gegee moet word en waar daar nuut gedink moet word, is ten opsigte van die toerusting van diakens self. Hulle sal moet besef dat hulle meer as net kollektante is en dat die diakensamp in die volle sin van die woord herstel sal moet word. Lidmate sal ook toegerus moet word sodat hulle hulle diakonale bediening sal verstaan en aktief sal deelneem aan die diakonaat van die gemeente. 
Verder sal die diakens en die lidmate moet besef dat diakonaat nie net 'n binne gemeentelike bediening is nie, maar dat diakonaat ook 'n missionêre karakter het, en dat juis ook dit deel van elke lidmaat se opdrag en roeping is.

\subsection{Lidmaatbetrokkenheid en toerusting}

Daar word dikwels in gesprekke verwys na die lidmaat se verantwoordelikheid ten opsigte van barmhartigheid. Die praktyk wys egter dat dit die diakens is wat die verantwoordelikheid vir die identifisering van nood en vir die omsien daarna op hulle neem. "Omdat daar soms 'n gelate aanvaarding kom dat die lidmate nou ten ene male nie so ver kom om geaktiveer te raak vir die barmhartigheidstaak nie, neem die diakonie en die res van die kerklike struktuur maar die beplanning en organisering en uitvoering van die werk oor. So ontstaan 'n bose kringloop wat tot nadeel is vir die diakonale aard van die gemeente" (Rossouw 1991:489).

Die meeste lidmate in 'n gemeente het nog nooit geleer om die fisiese nood van ander raak te sien en om die verantwoordelikheid tot die identifisering en aanspreek van nood as deel van die uitleef van hulle geloof te aanvaar nie. Mense dink dat dit in die kerk net om die geestelike nood van mense gaan. "We are captivated by the spiritual, internal life of the individual to the point that the whole life situation of people is deemphasized" (Kysar 1991:103). In elke gemeente sal daar 'n sensitiwiteit vir mense in nood gekweek moet word. "Die kille gelatenheid waarmee offergawes vir hierdie diens gebring word in 'n gesindheid van totale onbetrokkenheid, sal moet plek maak vir 'n gesindheid van diepe dankbaarheid, opregte medelye en 'n diepe bewoënheid vir die leed van andere. Barmhartigheidsdiens is en bly primêr 'n gemeentelike aksie" (Booysen 1993:56).

Die diakens sal die gemeente dus voortdurend moet toerus vir barmhartigheidsdiens. "Deacons are the church's teachers on matters of charity and justice" (McKee 1989:109). Daar sal 'n klemverskuiwing moet plaasvind ten opsigte van die wyse waarop die gemeente betrek kan word. Dit mag nie gesien word as net die blote bereidwilligheid om bepaalde offergawes of middele ten dienste van die diakens te stel nie. Elke lidmaat sal aangemoedig moet word tot aktiewe deelname. "The dynamic or prophetic function of the diaconate includes empowering and challenging or inspiring individual church members in their own 
diaconal work" (McKee 1989:111). Die diakonaat is en bly dus die taak en verantwoordelikheid van elke gemeentelid.

\subsection{Na buite}

Volgens Vos (2001:55) het geloofsgemeenskappe, wat meewerk aan die uitbouing van die koninkryk van God die funksie teenoor die wêreld te vervul as "benefactors through the function of diakonoi with a view to koinonia."

Die kerk behoort sy lidmate dus aan te moedig en toe te rus om mekaar en die wêreld met die koinonia en die diakonia te bedien (Oosthuizen en Strauss 1995:62). Blyth en Robins (1998:25) sluit hierby aan wanneer hulle sê:

... the interconnection between diakonia - Christian service - and koinonia - fellowship - is very strong ... service is complementary to the building up of the community ... The effect of the service which is called for by their Christian commitment is only really worthwhile if it helps to ensure the growth and development of the community and benefits all. Service is not self-serving; not designed to make those who serve feel good. This may be a side effect but it's aim is to bring greater well-being and justice to those who are served .... Koinonia and diakonia are part of an inseparable whole. Diakonia does not exist outside of fellowship. Koinonia which does not find within itself an expression of diakonia, is impaired and incomplete fellowship .... The liturgy gathers together the worship of the community and feeds the individuals of which it is composed. It prepare them for what follows and causes them to continue their praise and worship in the service that they offer throughout the week.

Peters (2000:14) steun hierdie siening wanneer hy sê: "In het kader van het missionair gemeentezijn komen we ook steeds meer tot de ontdekking dat apostolaat en diaconaat niet meer 'los verkrijgbaar' zijn, maar elkaar aanvullen. Het ene kan soms niet goed zonder het andere functioneren."

Daar was 'n tyd toe daar gedink is dat die verhouding van die individu met God al is wat saakmaak en dat dit die enigste saak op die kerk se missionêre agenda was. "It takes the shape of the view that one's private relationship with God is all that matters. The 'salvation of the soul' regardless of the state of the body is of utmost importance .... Christian spiritualism becomes therefore an incentive to ignore the social, political, economic conditions of people and to 
focus exclusively on their spiritual welfare" (Kysar 1991:103). Die dae toe evangelisasie net beteken het om siele vir die Koninkryk te wen, is met ander woorde verby.

Evangelisasie beteken dus eerder ' $n$ holistiese benadering tot die mens wat buite die gemeente staan. Sy geestelike sowel as fisiese en emosionele behoeftes moet raakgesien en aangespreek word. Engelbrecht (1957:19) bepleit dan ook juis 'n diakonale betrokkenheid wat weier as net die gemeentegrense strek. Hy skryf: "Dikwels word ons diakenswerk alleen beperk tot so 'n bietjie hulp met kos en klere aan armes .... En laat ons verder ook hierby nie hulle wat vreemdelinge is (bv immigrante) en hulle wat in die gevangenis en siek is, vergeet nie. Ons mag miskien nie van hierdie mense hou nie, maar laat ons soos Hy met ons, Sy vyande, medelye gehad het, dit ook met hulle, die geringstes hê, want vir sover as wat ons dit aan een van hulle doen, doen ons dit aan Hom."

Volgens Engelbrecht (1957:20) moet ons onthou dat ons diakonaatsopdrag nie net tot die klein kring van ons eie gemeente beperk is nie. "Die 'heilige algemene, Christelike kerk' is veel, veel groter as ons gemeente, en ons word ook opgeroep tot hierdie wyer en groter diens. Jesus het ook nie net barmhartigheid bewys aan mense van die kerk van sy dae nie, maar ook aan ander volke bv. Samaritane en Romeine wat in nood verkeer het."

Voorts sê Engelbrecht (1957:21) dat diakonaat "nie net tot ons eie gemeente en volk beperk is nie, maar sig ook in dankbare woord en daad moet uitstrek tot Christene van ander lande en volke. Dit sal natuurlik swaar verpligtinge op ons lê, maar as die arm gemeentes van Macedonië ryk kon wees in hulle milddadigheid vir hierdie liefdeswerk, en selfs bo vermoë gewillig was, dan kan en behoort ons dit ook te doen."

Dit is ook die punt wat Nel (1994:47) maak. Volgens hom is God reeds en steeds aktief besig in sy wêreld. "Hy is ook aktief besig in die gemeenskap waarbinne elke gemeente bestaan. Die gemeente is in die sin sy mense wat vir sy barmhartigheid sensitief geraak het. Soos niemand anders nie weet die gemeente dat God omgee en dat dit vir Hom saak maak wat van mense in hulle nood word. Hulle weet ook eerstehands dat God in staat is om te help ... Barmhartigheidsdiens is daarom die mees logiese diens wat die gemeente in sy missionêre gerigtheid op God se wêreld kan lewer. Dit is niks anders as missionêre diens of diakonaat nie. So neem die gemeente deel aan dit waarmee 
God besig is. Hulle raak betrokke by dit wat God reeds uit liefde doen vir mense in en rondom die gemeente - mense in hulle bestaan van sonde, hartseer, ongeregtigheid, onderdrukking, intimidasie, armoede, werkloosheid, eensaamheid, geweld en nog meer."

"Juis hierin is die plaaslike gemeente missionêr by sy gemeenskap betrokke dat hy uitdrukking gee, ook in sy strukture, aan God se barmhartige hulpvaardigheid. Die vraag van die gemeente is voortdurend hoe hulle Christus se dienswerk om hulp te verleen en hoop te gee in hulle omgewing konkreet maak" (Nel 1994:232). Die pleit is dus vir 'n diakonale gemeente. En 'n diakonale gemeente is volgens Peters (2000:74) ' $n$ gasvrye gemeente. Dit is een van die grootste gawes waaroor 'n gemeente moet beskik. 'n Gemeente moet volgens hom soos 'n herberg wees.

Dat roept een beeld op van een kerk die staat langs de wegen van mensen, die open en gastvrij, uitnodigend is. Een kerk die niet probeert mensen binnen te houden - te bekeren, maar hen van al het nodige wil voorzien zodat zij hun eigen weg gesterkt, misschien zelfs met blijdschap, kunnen vervolgen; die gasten de kans geeft hun verhaal te vertellen en naar dat van anderen te luisteren; die ook de mogelijkheid biedt voor beraad om samen in actie te komen.

Diakenswerk is dus nie blote welsynswerk nie. Dit is en bly in die eerste instansie ook kerkwerk en daarom is dit ook verkondigingswerk. Noordegraaf (1991:182) stel dit soos volg: "Zonder opdringerigheid, zonder valse pretenties zullen diakenen bescheiden, maar duidelijk mogen laten horen dat fundamenteel voor alle welzijn het herstel van de relatie met God door Jezus Christus is ... Diakonaat is immers geworteld in de dienst van Christus Diakonos, de Redder van ons totale bestaan."

\section{DIAKONIA AS GEMEENTEBEDIENING}

Die diepste fundering vir die diakonia in die kerk is geleë in die werk van Jesus Christus self. Hy is die Dienskneg wat tot die uiterste toe gedien het en wat nog steeds met die Vader en die Heilige Gees diensknegte van Hom roep en aanstel om diens te lewer ter wille van die diens van sy kudde. "Diens in navolging van Christus is in groot mate meer as ' $n$ doel, dit is deel van die bestaanswyse van 
die gemeente. Dit is die ware identiteit van die gemeente van God. Die gemeente loop as leerlinge agter die Diakonos aan. By Hom, uit sy Woord, leer die gemeente elke dag wat diens eintlik is" (Nel 2001b:72).

Die diens van Christus is daarom van fundamentele en beslissende betekenis vir die ganse dienswerk en veral barmhartigheidswerk van sy kerk (Coertzen 1995:344). Peters (2000:29) sluit hierby aan en voer die argument verder deur te sê dat 'n "diaconale levenshouding heeft grote missionaire betekenis ... om de liefde van Christus present te stellen en te laten zien wat het evangelie voor mens en sameleving kan betekenen. Als de christelijke gemeente er in slaagt op de wereld betrokken liefdesgemeenschap te zijn, zal ze herkenbaar zijn en aantrekkingskracht uitoefenen. Diaconaat is verklaring van het evangelie in de taal der handen." Die manier waarop Jesus gedien het, en selfs sy dissipels se voete gewas het, was dus nie bedoel om 'n unieke uitsondering in die geskiedenis van die mensdom te wees nie. "The way in which Jesus behaved towards his disciples became the way we should behave towards one another" (Bach 1988:124).

Binne die gemeente is daar niemand wat uitgesluit is van die barmhartigheid van God nie, gevolglik het elkeen dan ook 'n taak en 'n verantwoordelikheid om self ook barmhartigheid te bewys (vgl Booysen 1993:51).

Hierdie dienswerk in die gemeente moet beslis nie net deur die ampte, en dan veral die diakens, verrig word nie. Volgens die Skrif (bv 1 Kor 12) moet die gemeentelede self ook baie aktief wees. Die doel van die ampte in die kerk is ook nie om die werk van die gemeentelede uit hulle hande te neem nie maar juis om die gemeentelede tot diens te aktiveer. "... the reasons our ministries to social needs are weakened is that we have not examined and altered the fundamental consciousness of ... our congregations" (Kysar 1991:101).

In Efesiërs 4:11 en 12 staan daar dat dit Christus is wat die ampsdraers aan sy kerk gegee het en dat hulle die taak het om die gelowiges toe te rus vir hulle dienswerk en vir die opbou van die liggaam van Christus sodat ons almal uiteindelik sal kom tot die werklike eenheid in ons geloof en in ons kennis van die Seun van God.

Volgens Efesiërs 4:12 was dit die taak van die apostels, profete, evangeliste en die herders en leraars (die ampte in die vroeë kerk) om die gelowiges toe te rus vir hulle diens en vir die opbou van die liggaam van Christus. Die sogenaamde "ampte" is deur Christus as gawes aan die gemeente 
gegee om die gelowiges toe te rus sodat hulle dan op hulle beurt weer hulle diens kan verrig met die gawes wat hulle ontvang het. Sodoende word die liggaam van Christus opgebou (Coertzen 1995:345).

... ieder gemeentelid maakt deel uit van de gemeenschap en heeft dus ook gaven gekregen. Zowel materieel (bijv geld, goederen, handvaardigheid, hulpverlening, creativiteit) als niet-materieel (bijv pastoraal werk, bezoekwerk, onderwijs, leidinggeven, verkondigen, troosten, begeleiden). Niemand kan zich aan deze gemeenschap onttrekken. Je hoort erbij (via doop en belijdenis) of je hoort er niet bij. Hiervoor is nodig een houding van dienstbetoon vanuit het principe: niet heersen maar dienen.

(Peters 2000:58)

Volgens Coertzen (1995:345) beteken die woord "toerusting" in Ef 4:12 "dat iemand in staat gestel word om te doen wat daar van hom verwag word." Toegepas op die toerusting van die gelowige deur die ampte, beteken dit dat dit die taak van die ampte is om aan elke lid van die liggaam die toerusting te verskaf wat nodig is sodat hulle kan voldoen aan dit wat van hulle verwag word op grond van die gawe wat hulle van die Heilige Gees ontvang het. Of soos Nel (2001a:121) dit stel: "Hy skenk aan hulle mense as gawes om mense met gawes voor te berei vir hulle diens."

'n Diakonale gemeente is dus 'n gemeente wat tot die besef gekom het dat elke lidmaat ook 'n diakonale funksie het en wat die lidmate dan toerus om hierdie funksie te vervul. Selfs ook die jeug. "Daar is by die jeug aan die een kant 'n opvallende selfsug wat a-diakonaal is en tog aan die ander kant 'n verrassende gereedheid vir diens wat by hulle ouderdomsfase pas" ( $\mathrm{Nel}$ 2001b:93). Hierdie dienende funksie moet in die daaglikse lewenswandel van die totale gemeente tot uiting kom - vanuit die diens aan mekaar in die verbondsgesin; die onderlinge opbou en bystand in die gemeente, tot by die dienslewering in die samelewing. "Een diaken en een diakonale gemeente dienen een Here die een kruis gedragen heeft, en worden geroepen tot navolging van de Gekruisigde" (Noordegraaf 1991:167).

Die diaken se plig is dus om die nood raak te sien, ander te mobiliseer om daarby betrokke te raak, kundigheid te verleen waar nodig en self die voorbeeld 
te stel van diens. Self moet hy nie die werk oorneem en alles wil doen nie - so word die lidmate tot onmondigheid gedwing en is die uiteinde 'n eenmansvertoning.

Die tweede belangrike aspek rakende 'n diakonale gemeente is die gerigtheid na buite. "Naas die aksent op die onderlinge diakonaat en opbou is die gerigtheid na buite ewe belangrik. Daarsonder is die gemeente gedoem tot 'n eiegeregtige warmbroeiery van mekaar ten koste van ander ..." (Rossouw 1991:492).

Diakonaat met ' $n$ missionêre perspektief is dus van wesenlike belang vir elke geloofsgemeenskap wat gehoorsaam aan die Woord, gemeente van ons Here Jesus Christus in hierdie wêreld wil wees. Die verantwoordelikheid van die gemeente om as dissipel in die wêreld getuigend met dienswerk besig te wees, sal weer aan die hart van elke lidmaat gebind moet word.

Elke gemeente sal dus kreatief na die samelewing waarbinne hulle gemeente is, moet gaan kyk. Hulle sal die vraag moet beantwoord: Waarom het die Here ons geroep om juis hier, binne hierdie bepaalde gemeenskap en op hierdie spesifieke plek kerk te wees. Die nood en behoefte van die omgewing sal geanaliseer moet word en dan sal daar besluit moet word op watter wyse die gemeente diakonaal en missionêr daarby betrokke kan raak. 'n Ander aspek wat in gedagte gehou moet word, is dat die diakonie nie die enigste is wat die nood van die samelewing in die oog het nie, “... integendeel, zij vinden naast zich een leger van hulpverleners en helpende instanties die beroepsmatig zich inzetten om de kwaliteit van het menselijk bestaan te verbeteren en mensen te helpen in situaties van onwelzijn .... Dat alles stelt diakenen voor de vraag, op welke wijze hun arbeid ingevoegd moet worden in het geheel van voorzieningen en instellingen" (Noordegraaf 1991:159).

Sporte (1996:124) het 'n studie onder 25 gemeentes in Amerika gedoen om te kyk na die diakonale dienslewering wat hulle op missionêre vlak buite die gemeentegrense verrig. Hierdie lys kan 'n gemeente se visie help verbreed en dalk nuttig wees wanneer die ondersoek in die eie omgewing gedoen word, daarom noem ek 'n paar:

- Op die gebied van opvoeding en onderrig het hy (1996:124-126) die volgende geïdentifiseer: 
- $\quad$ 'n Jeugontwikkelingsprogram wat onder jeugmisdadigers geloots is om vir hulle vaardighede aan te leer sodat hulle op 'n eerbare wyse ' $n$ inkomste kan verdien;

- 'n Geletterdheidsprogram aan volwassenes wat nie 'n basiese onderrig ontvang het nie, sodat hulle ten minste kan lees en skryf om sodoende 'n werk te bekom met die doel om selfonderhoudend te word;

- $\quad$ 'n Jeugprogram om jongmense te leer om gesond te ontspan en om hulleself kultureel uit te druk;

- 'n Program om immigrante 'n nuwe taal aan te leer, asook vaardighede in wiskunde, rekenaargeletterdheid en kuns;

- $\quad$ By verskeie gemeentes bestaan daar naskoolsentrums om kinders te akkommodeer wiese ouers nie na-skool fasiliteite kan bekostig nie.

- Ten opsigte van die versorging van bejaardes (Sporte 1996:127-128) is daar die volgende projekte:

- 'n Dagsorgkliniek vir bejaardes. Baie bejaardes woon in by hulle kinders. Die kinders werk gedurende die dag en is dan bekommerd oor die versorging van hulle bejaarde ouers. Die bejaardes word by die kerk se dagsorgkliniek afgelaai en na werk weer daar opgelaai. Die sentrum verskaf warm etes en stimulerende aktiwiteite. Op baie plekke dien die sentrum ook as bymekaarkomplek vir die hele gemeenskap se bejaardes.

- Daar is ook gemeentes wat die dagsorgsentrum met 'n naskoolsentrum kombineer. Die bejaardes help dan in die middae met die oppas van die kinders en hulle sien toe dat die huiswerk gedoen word.

- $\quad$ 'n Geval word vermeld waar die bejaardes en die kinders saam op 'n oop stuk veld 'n tuin aangelê het en so, afgesien van die terapeutiese 
en opvoedkundige waarde wat dit vir beide groepe inhou, ook in die sentrum se groente behoeftes voorsien het. Daar was selfs genoeg groente om te verkoop en so kon van die ander uitgawes gedek word.

- Ten opsigte van behuising het Sporte (1996:128-130) die volgende projekte gelys:

- 'n Gemeente het 'n herstelkomitee op die been gebring om huise te herstel en op te knap vir lae-inkomste families en senior burgers;

- $\quad$ 'n Gemeente, wat in 'n omgewing is waar mense baie verhuis, het 'n tussentydse behuisingsprojek geloots om aan mense verblyfplek te verskaf wat van die een huis/of dorp/of werk, na die ander oorbeweeg;

- Dan was daar ook 'n paar traumasentrums of tuistes waar veral mishandelde vroue en kinders tydelik gehuisves kan word.

- Ander diakonaal-missionêre projekte wat hy lys, is onder andere:

- Gemeenskapsprogramme wat aangebied word om jongmense van die strate af te hou;

- $\quad$ Kos wat aan straatkinders uitgedeel word;

- $\quad$ 'n Program om families te ondersteun terwyl hulle besig is om hulle voete te vind en vir hulle 'n entrepreneursaak van die grond af te kry;

- $\quad$ 'n Dienswerkspan bestaande uit tieners wat tuindienste verrig om gestremdes en ander persone wat dit nie self kan doen, of kan bekostig nie, te help;

- Dan is daar ook gemeentes wat hulle fasiliteite beskikbaar stel vir gemeenskapsaktiwiteite; 
- $\quad$ Afgetrede persone wat hulle vaardighede gratis beskikbaar stel soos om te help met die invul van belastingvorms, bemiddelingswerk tussen 'n aanklaer en aangeklaagde voordat die saak in die hof hoef te draai, of om nuusblaaie en gemeenskapskoerante af te lewer;

- Daar was ook 'n groep mense wat as bemiddelaars tussen dowes en horendes opgetree het.

Peters (2000:75) lys ook projekte waarop hy in sy navorsing afgekom het onder 'n aantal Nederlandse gemeentes. Die projekte behels onder meer:

- $\quad$ Om blyplek aan daklose mense te verskaf;

- $\quad$ Diensbeurte by 'n sentrum vir terminale pasiënte;

- Hulpdienste beskikbaar te stel om bv. vir bejaardes medisyne te gaan oplaai, of inkopies te doen, kinders vir mense in noodgevalle op te pas, gaan stap met rolstoelpasiënte, siek mense dokter toe te neem, vir bejaardes en blindes voor te lees uit die Bybel of koerante en tydskrifte, om biblioteekboeke vir bejaardes om te ruil;

- $\quad$ Dan is daar ook maaltydprojekte vir siekes, bejaardes en kinders by skole; Ondersteuningsgroepe vir mense wat besig is om hulle rou te verwerk, mense wat deur traumatiese ervarings is, kinders met kanker en gerehabiliteerdes;

- $\quad$ 'n Projek om aan vreemdelinge en vlugtelinge hulp te verleen want gewoonlik kom hulle uit lande waar daar of oorlog, of hongersnood en armoede heers;

- $\quad$ Dan bied baie gemeentes ook 'n koinonia geleentheid vir nuwe intrekkers;

- Daar is ook gemeentes wat kursusse aanbied oor dienslewering en die benutting van jou gawes. 
Volgens Nel (1994:232) behoort die gemeente die barmhartigste organisme op aarde te wees - hier moet die hartklop van die barmhartige God tasbaar gevoel en ervaar word. Ons moet toesien dat ook ons diakonale strukture in die gemeente ten diepste die kommunikasie van die goeie nuus en die heil wat Christus gebring het, dien.

\begin{abstract}
Vrae wat dus vanuit hierdie beginsel aan die bedieningsvorme of strukture van die gemeente gevra moet word, is: maak die strukture die vloei van die barmhartigheid van God en sy mense maklik? Is dit moontlik om vinnig hulp en hoop te verleen aan diegene wat onverwags in nood kom? Is die strukture vir hulpverlening "mensvriendelik"? Word die menswaardigheid van die mens in nood gehandhaaf of aangetas? Maak die strukture en vorme dit maklik vir mense wat hulp en hoop ontvang, om in te skakel in die gemeenskap van mense wat omgee en die lewe met mekaar deel?
\end{abstract}

(Nel 1994:233)

In 'n gemeente met 'n missionêre diakonaatsbediening word die diakonaat nie in die eerste plek ter wille van die bekering van mense gedoen nie. Die diakonaat word gedoen omdat God daardeur sy son laat skyn oor goeies en slegtes.

"Tog" sê Nel (1994:232), "lewer die diakonaat ook sy groeivrug - mense kom tot geloof in die barmhartige God." Die evangelie word gekommunikeer, mense hoor, ervaar en proe dit. Hulle word met God versoen en so word hulle deel van sy volk. "God's family owes one another faith, hope and love .... In the Father's household people live not only on grace, but also on bread. We obtain grace from the Father as a gift. We owe one another daily bread" (Vos 2001:66).

Die kerk moet die sluise van die charismata wat in die duisende lidmate opgesluit lê, ooptrek sodat die volle krag van Goddelike barmhartigheid en weldadigheid sigbaar en voelbaar sal wees in ons wêreld vol nood en ellende. As die gemeente onder leiding van die diakonale amp, hierdie verantwoordelikheid opneem en dit as daadgetuienis elke dag uitleef, sal die kerk getransformeer word tot waardige vaandeldraer van die ware evangelieboodskap van God in Jesus Christus (Rossouw 1991:495). 


\section{Literatuurverwysings}

Bach, U 1988. "But if you say so!" A plea for a church of the diakonia, in Greinacher \& Mette 1988:20-39.

Blyth, M \& Robins, W 1998. No boundaries to compassion? Geneva: WCC.

Botha, S J 1993. Kerklike barmhartigheid in die loop van die kerkgeskiedenis, in Booysen 1993:40-49.

Booysen, D J, 1993. Die diens van barmhartigheid. Pretoria: Kital.

Booysen, DJ 1993. Die diens van barmhartigheid in die praktyk, in Booysen 1993:50-65.

Broederkring van die ring van Potchefstroom. Handleiding vir kerkraadslede.

Coertzen, P 1995. Ampte in die kerk. NGTT 36(3), 343-352.

Dudley, C S 1996. Next steps in community ministry. New York: Alban Institute.

Engelbrecht, B J 1957. Die amp van die diaken. Krugersdorp: NHW-PERS.

Greinacher, N \& Mette, N 1988. Diakonia church for the others. Edinburgh: T \& T Clark.

Koekemoer, P J T 1993. Fundering, vertrekpunt en wese van ons barmhartigheidsdiens, in Booysen 1993:1-39.

Kysar, R 1991. Called to care. Minneapolis: Fortress Press

McKee, E A 1989. Diakonia in the classical reformed tradition and today. Grand Rapids: Wm B Eerdmans.

Mead, L B 1993. The once and future church. New York: The Alban Institute.

Moltmann, J 1997. The Church in the power of the Spirit. London: SCM Press.

Nel, M 1994. Gemeentebou. Halfway House: Orion.

Nel, M 2001a. Ek is die verskil. Bloemfontein: CLF-Drukkers.

Nel, M 2001b. Jeugbediening. Bloemfontein: CLF-Drukkers.

Noordegraaf, A 1991. Oriëntatie in het diakonaat. Zoetermeer: Uitgeverij Boekencentrum.

Oosthuizen, A \& Strauss, P 1995. Gemeentediakonaat as plaasvervanger vir staatsondersteunde sinodale barmhartigheidsdiens in die NG Kerk. Acta Theologica 15 (2), 50-65. 
Peters, A 2000. Tot Uw dienst: Een diakonale bijdrage aan gemeenteopbouw. Zoetermeer: Uitgeverij Boekencentrum.

Rossouw, P J 1991. Die gemeente as diakonale gemeenskap in die jare ' 90 . NGTT 32(3), 485-495.

Sporte, S E 1996. Stories and status of church and community ministries, in Dudley 1996:40-48.

Vos, C J A 2001. God's household and the poor in contextual ecclesiology. HTS $57(1 \& 2), 49-69$. 